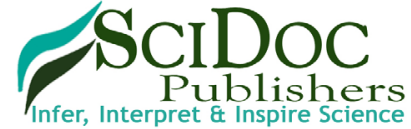

International Journal of Food Science, Nutrition and Dietetics (IJFS)

ISSN:2326-3350

\title{
Isolation and Quantification of Lycopene and Determination of B-Carotene and Total Phenolic Contents from Tomato (Lycopersicum Esculentum) by using Various Methods
}

Research Article

\author{
MK Akter ${ }^{1}$, M Motalab $^{2}$, MA Zubair ${ }^{1}$, MZ Haque 2 , BK Saha ${ }^{2 *}$, B Mumtaz ${ }^{2}$
}

${ }^{1}$ Department of Food Technology and Nutritional Science, Mawlana Bhashani Science and Technology University, Tangail, Bangladesh.

${ }^{2}$ Institute of Food Science and Technology, Bangladesh Council of Scientific and Industrial Research, Dhaka, Bangladesh.

\section{Abstract}

Introduction: The study was conducted on isolation and quantification of lycopene and determination of $\beta$-carotene and total phenolic contents from tomato.

Methods: Different solvent extraction methods were used and solvent extracts were analyzed by Spectrophotometer. There was significant difference observed among the lycopene, $\beta$ - carotene and total phenolic content of tomato fruits in different solvent extractions.

Results: Hexane: ethanol: acetone (2:1:1) solvent extract contain highest quantity of lycopene i.e. $6.76 \mathrm{mg} \%$ of fresh weight (F.W) which is significantly higher than ethyl acetate extract $(0.86 \mathrm{mg} \%$ of F.W.). Acetone-petroleum ether extract from tomato paste contain higher quantity of lycopene $(1.83 \mathrm{mg} \%$ F.W.) than Acetone-petroleum ether extract $(0.10 \mathrm{mg} \%$ fresh wt.) from tomato powder. Ethyl acetate with soxhlet extract has comparatively high content of lycopene i.e. $1.07 \mathrm{mg}$ $/ 100 \mathrm{~g}$ of F.W which is significantly more than ethyl acetate with normal extract i.e. $0.86 \mathrm{mg} / 100 \mathrm{~g}$ F.W. Ethyl acetate extract has the highest content of $\beta$-carotene $(3.84 \mathrm{mg} / 100 \mathrm{~g} \mathrm{F.W}$ ) which is significantly more than ethyl acetate with soxhlet extract but ethyl acetate with soxhlet extract i.e. $1.59 \mathrm{mg} / 100 \mathrm{~g}$ has a comparatively high content of $\beta$-carotene than acetone - petroleum ether extract $(0.52 \mathrm{mg} / 100 \mathrm{~g}$ F.W). Soxhlet extract contained comparatively higher content of total phenolic content (i.e. $118.08 \mathrm{mg} / 100 \mathrm{~g}$ F.W. with tannic acid reference standard in n-hexane: ethanol (4:3) solvent extract) than normal solvent extract.

Conclusions: Hexane: ethanol: acetone (2:1:1) solvent extract contain highest quantity of lycopene. Ethyl acetate extract has the highest content of $\beta$-carotene and Soxhlet extract contained comparatively higher of total phenolic content.

Keywords: Lycopene; Beta Carotene; Total Phenolic Content; Tomato.

\section{Introduction}

Lycopene is an important biological compound and has received great interest in the past decade because of its important role in preventing chronic diseases such as atherosclerosis, skin cancer and prostate cancer [9]. It is an antioxidant that displays higher efficiency than vitamin $\mathrm{E}$ and other kinds of carotenoids. A wellbalanced diet usually contains an adequate lycopene intake. The recommended daily intake of lycopene is 70 to 75 milligrams, and consuming some lycopene every day is beneficial to health [2].

Lycopene, a fat soluble carotenoid, is a precursor of $\beta$-carotene and has at least twice the antioxidant capacity of $\beta$-carotene [6]. Good amounts of lycopene are contained in many natural products, like ripe mango, tomato (Lycopersicon esculentum), water-melon, red pepper, black berry, papaya etc., [3]. In the last few years the importance of lycopene rapidly increased due to its pharmacological and anti-carcinogenic properties $[8,13]$.

Lycopene, a red carotenoid pigment in tomatoes and tomatobased products, is an acyclic form of beta-carotene without pro-vitamin A activity. It has attracted substantial interest during recent times for its beneficial in reducing oxidative stressing coronary heart diseases and other chronic diseases $[1,16,17,19]$. Its

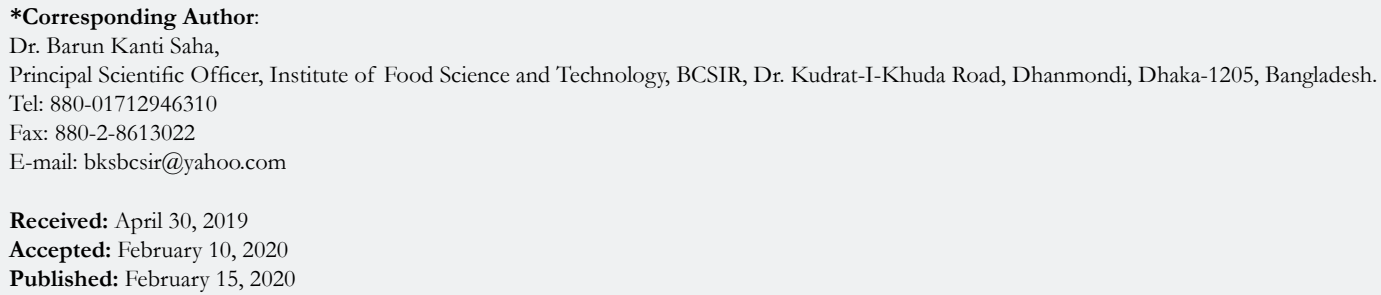

Citation: MK Akter, M Motalab, MA Zubair, MZ Haque, BK Saha, B Mumtaz. Isolation and Quantification of Lycopene and Determination of B-Carotene and Total Phenolic Contents from Tomato (Lycopersicum Esculentum) by using Various Methods. Int J Food Sci Nutr Diet. 2020;9(1):442-447. doi: http://dx.doi.org/10.19070/2326-3350-2000079

Copyright: Barun Kanti Saha ${ }^{\circ}$ 2020. This is an open-access article distributed under the terms of the Creative Commons Attribution License, which permits unrestricted use, distribution and reproduction in any medium, provided the original author and source are credited. 
molecular weight is $536.89 \mathrm{Da}$ and molecular formula is $\mathrm{C}_{40} \mathrm{H}_{56}$ with $89.45 \%$ carbon and $10.51 \%$ hydrogen.

It is highly unsaturated hydrocarbon containing 11 conjugated and two unconjugated double bonds [4, 7]. Molecular structure of lycopene is following.

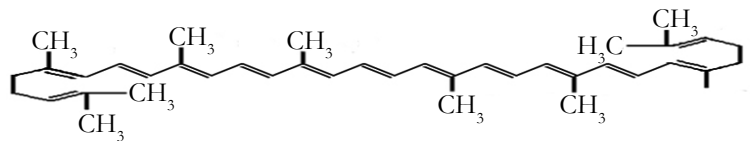

\section{Methods and Materials}

\section{Collection of Samples}

Tomato fruits samples were collected from the local market of Dhaka city. Special care was taken to select the most mature samples. Samples were first chopped and homogenized and then used to determine different chemical parameters and extract lycopene, $\beta$-carotene and total phenolic contents.

\section{Chemicals, Solvents and Ingredients}

The following solvents or mixture of solvents were used to identify the best solvent for extracting lycopene from tomato paste. All solvents were analytical grade, and water was distilled, deionized.

n-Hexane 95\% $\left(\mathrm{C}_{6} \mathrm{H}_{14}\right)$ - flammable liquid, analytical grade, Ethyl acetate $\left(\mathrm{CH}_{3} \mathrm{COOC}_{2} \mathrm{H}_{5}\right)$ - flammable liquid, Petroleum ether (BP $\left.40-60^{\circ} \mathrm{C}\right)$ - flammable liquid, irritating to skin, n-Hexane + ethyl acetate (1:1 by volume), Ethanol + ethyl acetate (1:1 by volume), n-Hexane + acetone + ethanol $(2: 1: 1$ by volume), n-Hexane + ethanol (4:3 by volume), Methanol, Aqueous Sodium Chloride, Aqueous Potassium carbonate, Calcium chloride (Drying Agent), Carbon tetrachloride, Benzene, Folin-Ciocalteu reagent, Sodium carbonate $\left(\mathrm{Na}_{2} \mathrm{CO}_{3}\right)$, Gallic acid, Tannic acid.

\section{Extraction Methods of Lycopene from Tomato Powder Sample}

\section{Soxhlet Extraction}

Samples $(1 \mathrm{~kg})$ were frozen. The frozen samples were placed in a freeze dryer system and then vacuum dried for 24 hours. After drying, sample was ground to a powder using a blender. Lycopene was extracted from dried samples by Soxhlet (solvent) extraction. To extract lycopene, duplicate, accurately weighed samples of dried tomato powder (approx. $5 \mathrm{~g}$ ) were placed in cellulose extraction thimbles (Whatman International Ltd., internal diameter 33 $\mathrm{mm} \times$ external length $100 \mathrm{~mm}$ ) and covered with glass wool. The thimbles were placed in the Soxhlet extraction unit and extracted for 20 hours with $150 \mathrm{ml}$ of one of the seven solvents. Boiling chips were added to each solvent-filled boiling flask and the hot water bath under each flask controlled to the boiling point of each solvent. Boiling point of solvents used:

\begin{tabular}{|c|c|}
\hline Solvent & Boiling Point \\
\hline n-Hexane & $68^{\circ} \mathrm{C}$ \\
\hline Ethyl acetate & $77^{\circ} \mathrm{C}$ \\
\hline Ethanol & $78^{\circ} \mathrm{C}$ \\
\hline Petroleum ether & $40^{\circ} \mathrm{C}$ \\
\hline
\end{tabular}

Once the solvent was boiling at a steady rate, each boiling flask was covered with aluminum foil to minimize heat loss. Extractions were done in the dark to minimize lycopene degradation and run for 20 hours to allow several refluxes.

The amount of solvent remaining in each boiling flask was measured to determine how much solvent evaporated during the extraction process. A known volume (approximately $2 \mathrm{ml}$ ) of the concentrate solvents were removed by pipette for lycopene analysis.

The remaining solvent was then evaporated in a water bath. An allowance was made for the sample that had been removed for lycopene determination. The dried concentrate containing the extracted lycopene was weighed.

\section{Methanol Extraction}

Fifty grams tomato paste was dehydrated by adding $65 \mathrm{ml}$ methanol. This mixture was immediately shaken vigorously to prevent the formation of hard lumps. After $2 \mathrm{hr}$, the thick suspension was filtered; the dark red cake was shaken for another 15 min with 75 $\mathrm{ml}$ mixture of equal volume of methanol and carbon tetrachloride and separated by filtration. The carbon tetrachloride phase was transferred to a separatory funnel; added one volume of water and shake well. After phase separation, the carbon tetrachloride phase was evaporated and the residue was diluted with about $2 \mathrm{ml}$ of benzene. Using a dropper, $1 \mathrm{ml}$ of boiling methanol was added in portion, then crystals of crude lycopene were appeared immediately and the crystallization was completed by keeping the liquid at room temperature and ice bath, respectively. The crystals were washed 10 times using benzene and boiling methanol.

The deep red zone was collected. After complete evaporation of solvent, the residue was dissolved in $2 \mathrm{ml}$ benzene. After recrystalization using boiling methanol, no colorless substances observed. Crystalline lycopene is not isomerized but has a tendency to autoxidation (or air oxidation), especially in light, so it was kept in dark evacuated glass tubes prior to use.

\section{Acetone - Petroleum Ether Extraction}

Sample (1.0-1.5 g powder) was extracted with $10 \mathrm{~mL}$ acetone-petroleum ether $(50 \% \mathrm{v} / \mathrm{v})$. The upper lycopene-containing organic layer was removed by means of a pipette and collected in test tube [15]. Extraction was repeated. The extracts were combined, washed with $15 \mathrm{~mL}$ saturated aqueous sodium chloride $(\mathrm{NaCl})$ and removed the aqueous wash with a micropipette. The extract was washed with $10 \mathrm{~mL}$ of $10 \%$ aqueous potassium carbonate $\left(\mathrm{K}_{2} \mathrm{CO}_{3}\right)$ and removed the aqueous wash. The lycopene-containing organic 
layer was dried with a drying agent (calcium chloride) [11]. The excess solvent was allowed to evaporate at room temperature for a few minutes in the dark. The tubes containing lycopene extracts were covered with aluminum foil and stored in freezer until further analysis.

\section{Determination of $\beta$-carotene and Lycopene from different Tomato extracts}

$\beta$ - Carotene was determined from the dried methanol extract according to Kumari et al., (2011). $100 \mathrm{mg}$ of extract was mixed with $10 \mathrm{ml}$ of acetone-hexane mixture (4:6) for $1 \mathrm{~min}$ and filtered. The absorbance was recorded at three different wavelengths (453, $505 \& 663 \mathrm{~nm})$. The $\beta$-carotene content was calculated by:

$\beta$-Carotene $(\mathrm{mg} / 100 \mathrm{~mL})=0.216 \times \mathrm{A} 663-0.304 \times \mathrm{A} 505+$ $0.452 \times$ A453.

Lycopene $(\mathrm{mg} / 100 \mathrm{~mL})=-0.0458 \times \mathrm{A} 663+0.372 \times \mathrm{A} 505-$ $0.0806 \times$ A 453 .

The results were presented as mg of $\beta$-Carotene/g of extract and lycopene/g of extract $\mathrm{mg}$ of $\beta$-Carotene $/ 100 \mathrm{~g}$ of raw tomato and lycopene $/ 100 \mathrm{~g}$ of raw tomato.

\section{Extraction Methods of Lycopene from Tomato Paste Sample}

\section{Ethyl Acetate Extraction Method}

Lycopene extract from tomato is a lycopene-rich extract prepared from the ripe fruits of tomato (Lycopersicon esculentum L.). The extract is produced by crushing tomatoes into crude tomato juice that is then separated into serum and pulp. The pulp is subsequently extracted using ethyl acetate as a solvent. The final product is obtained after solvent removal by evaporation under vacuum at $40-60^{\circ} \mathrm{C}$ (Type: RV 05-ST, Germany). The final extract consists of tomato oil in which lycopene together with a number of other constituents that occur naturally in tomato, are dissolved and dispersed.

The total lycopene and $\beta$ - carotene content was determined spectrophotometrically using a method according to Kumari et al., (2011).

\section{Hexane - Ethanol - Acetone Extraction Method}

Started with tomato juice, used a $1000 \mu \mathrm{l}$ micropipette to take the sample. Dispensed the sample into $15 \mathrm{ml}$ falcon tube. Added 8.0 $\mathrm{ml}$ of hexane: ethanol: acetone (2:1:1) using a micropipette. Cap and vortex the tube immediately then incubated out of bright light. After at least 10 minutes, or as long as several hours later, added $1.0 \mathrm{ml}$ water to each sample and vortex again. Let samples stand 10 minutes to allow phases to separate and all air bubbles to disappear. Rinsed the cuvette with the upper layer from one of the blank samples. Discarded, and then used a fresh blank to zero the spectrophotometer at $503 \mathrm{~nm}$. Determined the A503 of the upper layers of the lycopene samples.

Calculation of lycopene levels:
Lycopene content in the hexane extracts were calculated according to:

Lycopene (mg/kg fresh wt.) = A503 x 171.7/ W

Where, W is the exact weight of tomato added, in grams \& 171.7 $\mathrm{mM}-1$ is the extinction coefficient for lycopene in hexane.

\section{Acetone Petroleum Ether Extraction}

Lycopene content Ten grams of sample was weighed and extracted repeatedly with acetone using pestle and mortar till the residue became colorless. The acetone extract was transferred to a separating funnel containing $10-15 \mathrm{ml}$ of petroleum ether and mixed gently. Carotenoid pigments are collected in the petroleum ether fraction by diluting the acetone with water. The lower phase was transferred to another separating funnel and the petroleum ether extract containing pigments to an amber colored bottle. Extraction was repeated similarly with petroleum ether until it is colorless.

To the petroleum ether extract small quantity of anhydrous $\mathrm{Na}$ 2So4 was added and the volume made up to $50 \mathrm{ml}$. The color was measured in a quartz cuvette $503 \mathrm{~nm}$ in a spectrophotometer using petroleum ether as a blank.

Lycopene content of sample was calculated by using the relationship that optical density (OD) of $1.0=3.1206 \mu \mathrm{g}$ of lycopene per $\mathrm{ml}(20)$.

Lycopene content (mg/ 100g):

$=(3.1205 \times$ OD of the sample $\times$ Volume made up to $\times 100) / 1$ $\mathrm{x}$ Weight of the sample $\mathrm{x} 1000$

\section{Determination of Total Phenolic Content (TPC) in Tomato using Gallic Acid Standard and Tannic Acid Standard}

The amount of total phenolic content was determined by previous study with some modifications [5]. A $0.5 \mathrm{ml}$ of extract (concentration of extract is $1.0 \mathrm{mg} / \mathrm{ml}$ ) and $0.5 \mathrm{ml}$ of Folin-Ciocalteu reagent $(0.5 \mathrm{~N})$ were mixed and incubated at room temperature for $5 \mathrm{~min}$. Then $2.0 \mathrm{ml}$ saturated sodium carbonate $(30 \% \mathrm{w} / \mathrm{v})$ was added and the final volume was made up to $10 \mathrm{ml}$. It was further incubated for $30 \mathrm{~min}$ at room temperature and the absorbance was measured at $765 \mathrm{~nm}$. Gallic acid (GA) was used as positive control. Tannic acid [21] was also used as positive control. The absorbance was determined using spectrophotometer at $\lambda$ $=765 \mathrm{~nm}$. The absorbencies were read in triplicate for each analysis and the mean value of absorbance was obtained. The same procedure was repeated for the standard solution of Gallic acid and Tannic acid and the calibration lines were construed. Based on the measured absorbance, the concentration of phenolic was $\mathrm{read}(\mathrm{mg} / \mathrm{ml})$ from the calibration line; then the content of phenolic in extracts was expressed in terms of Gallic acid equivalent (mg of GA/g of extract) and Tannic acid equivalent (mg of TA/g of extract).

The contents of total phenolic was extrapolated by using the linear equation $\mathrm{Y}=98.41 \mathrm{x}-0.744(\mathrm{R}$ square is 0.985$)$ where $\mathrm{x}$ is 
absorbance and y is concentration of Gallic acid.

Similarly, the contents of total phenolic was extrapolated by using the linear equation $\mathrm{Y}=101.2 \mathrm{x}+1.965$ ( $\mathrm{R}$ square is 0.996$)$ where $\mathrm{x}$ is absorbance and $\mathrm{y}$ is concentration of tannic acid.

\section{Statistical Analysis}

All the analyses were carried out in triplicate, and then the results were expressed as average values along with their standard deviations (SD). The data were statistically analyzed by using the MS Excel software.

\section{Results and Discussions}

Lycopene was isolated by six different solvent extraction methods. Beta carotene and total phenolic content was extracted by three different solvent extraction methods as well as soxhlet extraction method using seven different solvents and different extracts were analyzed by using Spectrophotometer (Shimadzu Spectrophotometer UV-1800).

Extracted lycopene using petroleum ether shows only a small amount of lycopene and other carotenoids. The effect of ethanol on lycopene extraction from tomato powder using soxhlet extraction method was low comparative to other solvents which might suggest that it could be excluded from the extracting mixture. However, a positive synergistic secondary effect was found for ethyl acetate: ethanol (1:1) and hexane: ethanol (4:3) in the samples, suggesting that the inclusion of ethanol would improve extraction rates. Similar findings are reported by Tanugbodhitam et al., 1998, and Lin and Chen (2003), who observed that, the ethanol: hexane mixture $(4: 3, \mathrm{v} / \mathrm{v})$ increased lycopene extraction in tomatoes. Amount of lycopene in ethyl acetate extract was $1.07 \mathrm{mg} / \mathrm{g}$ raw tomato (Table 1 ).

Among the extraction methods used to extract lycopene from tomato powder the relatively low amount of lycopene was extracted by the methanol and acetone-Petroleum ether extraction methods (Table 1).

Higher amount of $\beta$-carotene (3.84 mg \% F.W) was found in ethyl acetate extraction while lower was found in acetone petroleum ether extraction. Using soxhlet extraction method amount of $\beta$-carotene in di-mixture solvents like ethyl acetate \&ethanol (1:1) and $\mathrm{n}$-hexane \& ethanol (4:3) were $2.48 \mathrm{mg}^{\circ} \% \mathrm{~F} . \mathrm{W}$ and $2.20 \mathrm{mg}$ $\%$ F.W respectively. Beta Carotene content in Petroleum Ether, $\mathrm{n}$-hexane and ethyl Acetate solvent extract were 1.33, 1.08 and $1.59 \mathrm{mg}^{\%}$ F.W respectively. Amount of $\beta$-carotene content in other solvent extract like Ethanol, ethyl acetate: n-hexane (1:1) and methanol were almost similar shown in Table 2.

Lycopene content from tomato paste using various solvent and solvent mixtures was higher than from tomato powder. Higher amount of lycopene $(6.76 \mathrm{mg} / 100 \mathrm{~g}$ F.W $)$ was found in Hexane: ethanol: acetone (2:1:1) extraction and lower amount $(0.10$ $\mathrm{mg} / 100 \mathrm{~g}$ F.W. $)$ in acetone - petroleum ether extraction method. In contrast, the mixture hexane: ethanol: acetone (2:1:1) appeared

Table 1. Lycopene content from tomato powder using different solvent extraction methods (Quantity expressed as $\mathrm{mg} / 100 \mathrm{~g}$ ).

\begin{tabular}{|c|c|c|c|c|}
\hline SI. No. & Methods Name & Extract & $\begin{array}{c}\text { Lycopene } \\
(\mathrm{mg} / 100 \mathrm{~g} \text { F.W) } \\
\text { Mean } \pm \mathrm{SD}\end{array}$ & $\begin{array}{c}\beta \text {-carotene } \\
(\mathrm{mg} / 100 \mathrm{~g} \text { F.W }) \\
\text { Mean } \pm \mathrm{SD}\end{array}$ \\
\hline 1 & Soxhlet extraction & $\begin{array}{c}\text { Petroleum ether } \\
\text { n-hexane } \\
\text { Ethyl acetate } \\
\text { Ethanol } \\
\text { Ethyl acetate: } \mathrm{n} \text {-hexane }(1: 1) \\
\text { Ethyl acetate: Ethanol }(1: 1) \\
\text { n-Hexane: Ethanol }(4: 3)\end{array}$ & $\begin{array}{l}0.69 \pm 0.03 \\
0.83 \pm 0.03 \\
1.07 \pm 0.02 \\
0.23 \pm 0.03 \\
0.42 \pm 0.03 \\
1.16 \pm 0.05 \\
1.08 \pm 0.05 \\
\end{array}$ & $\begin{array}{l}1.33 \pm 0.09 \\
1.08 \pm 0.01 \\
1.59 \pm 0.05 \\
0.75 \pm 0.05 \\
0.87 \pm 0.01 \\
2.48 \pm 0.03 \\
2.2 \pm 0.05 \\
\end{array}$ \\
\hline 2 & Methanol extraction & Methanol & $0.15 \pm 0.02$ & $0.90 \pm 0.1$ \\
\hline 3 & $\begin{array}{c}\text { Acetone - Petroleum } \\
\text { ether extraction }\end{array}$ & Acetone - Petroleum ether & $0.10 \pm 0.02$ & $0.52 \pm 0.02$ \\
\hline 4 & Ethyl Acetate Extraction & Ethyl Acetate & $0.87 \pm 0.05$ & $3.84 \pm 0.04$ \\
\hline
\end{tabular}

Each value represents mean \pm SD; F.W represents Fresh Weight

Table 2. Comparison of Lycopene content between extraction of lycopene from tomato paste and tomato powder samples.

\begin{tabular}{|c|c|c|}
\hline Solvent & $\begin{array}{c}\text { Lycopene using Tomato } \\
\text { Paste(mg/100g F.W) }\end{array}$ & $\begin{array}{c}\text { Lycopene using Tomato } \\
\text { Powder (mg/100g F.W) }\end{array}$ \\
\hline Ethyl Acetate & 0.87 & 1.07 \\
\hline Acetone- petroleum ether & 1.83 & 0.1 \\
\hline Hexane- ethanol- Acetone & 6.76 & 1.08 \\
\hline Methanol & -- & 0.14 \\
\hline
\end{tabular}


to be much more effective. Since hexane is the only component of the mixture with a high affinity for lycopene, it follows that acetone and ethanol must play some auxiliary role in the overall extraction process. Considering that the tomato paste used had a lycopene content of $6.76 \mathrm{mg}$ per $100 \mathrm{~g} \mathrm{F.W}$, recoveries with the mixture hexane: ethanol: acetone (2:1:1) as the solvent (Table 2).

Lycopene content in tomato powder with methanol extract and acetone petroleum extract were $0.15 \mathrm{mg} / 100 \mathrm{~g}$ and $0.10 \mathrm{mg} / 100$ $\mathrm{g}$ fresh weight respectively.

Results of the total phenolic content presented in Table 3. When Gallic acid was used as a reference standard the higher amount of total phenolic content (61.34 mg /100 g F.W) was found in ethanol solvent extract. The lower amount of total phenolic content $(3.86 \mathrm{mg} / 100 \mathrm{~g})$ was found in hexane extract but a mixture of hexane-ethanol (4:3) increases the total phenolic contents $(31.65 \mathrm{mg} / 100 \mathrm{~g}$ F.W). The amount of total phenolic content in other solvent extracts like Petroleum ether, ethyl acetate, ethyl acetate: n-hexane (1:1) and ethyl acetate: ethanol (1:1) were 9.53, $19.02,51.04$, and $9.23 \mathrm{mg} / 100 \mathrm{~g}$ F.W respectively. The total phenolic content in tomato extract depends on the type of extract, i.e. the polarity of solvent used in extraction. High solubility of phenols in polar solvents provides high concentration of these compounds in the extracts obtained using polar solvents for the extraction $[14,22]$.

Table 3. Total phenolic contents in tomato using different extraction methods.

\begin{tabular}{|c|c|c|c|c|}
\hline SI. No. & Methods Name & Extract & $\begin{array}{l}\text { Total phenolic content } \\
\text { (mg GAE1/100 g F.W) }\end{array}$ & $\begin{array}{l}\text { Total phenolic content } \\
\text { (mg TAE } 2 / 100 \mathrm{~g} \text { F.W) }\end{array}$ \\
\hline 1 & Soxhlet extraction & $\begin{array}{c}\text { Petroleum Ether } \\
\text { n-hexane } \\
\text { Ethyl Acetate } \\
\text { Ethanol } \\
\text { Ethyl acetate: } n \text {-hexane }(1: 1) \\
\text { Ethyl acetate: Ethanol }(1: 1) \\
\text { n-Hexane: Ethanol }(4: 3)\end{array}$ & $\begin{array}{c}9.53 \pm 0.13 \\
3.86 \pm 0.06 \\
19.02 \pm 0.03 \\
61.34 \pm 0.08 \\
51.04 \pm 0.04 \\
9.23 \pm 0.07 \\
31.65 \pm 0.05\end{array}$ & $\begin{array}{c}10.46 \pm 0.05 \\
4.3 \pm 0.1 \\
20.91 \pm 0.1 \\
71.29 \pm 0.2 \\
94.53 \pm 0.08 \\
10.12 \pm 0.07 \\
118.08 \pm 0.04\end{array}$ \\
\hline 2 & Ethyl acetate extraction & Ethyl acetate & $12.24 \pm 0.05$ & $14.73 \pm 0.30$ \\
\hline 3 & Methanol extraction & Methanol & $10.47 \pm 0.08$ & $11.24 \pm 0.08$ \\
\hline 4 & $\begin{array}{l}\text { Acetone petroleum ether } \\
\text { extraction }\end{array}$ & Acetone petroleum ether & $6.94 \pm 0.05$ & $7.62 \pm 0.08$ \\
\hline
\end{tabular}

1= Gallic Acid Equivalent, $2=$ Tannic Acid Equivalent; the values are means \pm SD of three replicates.

Figure 1. Standard calibration curve for the determination of total phenolic contents using Gallic acid as a reference standard.

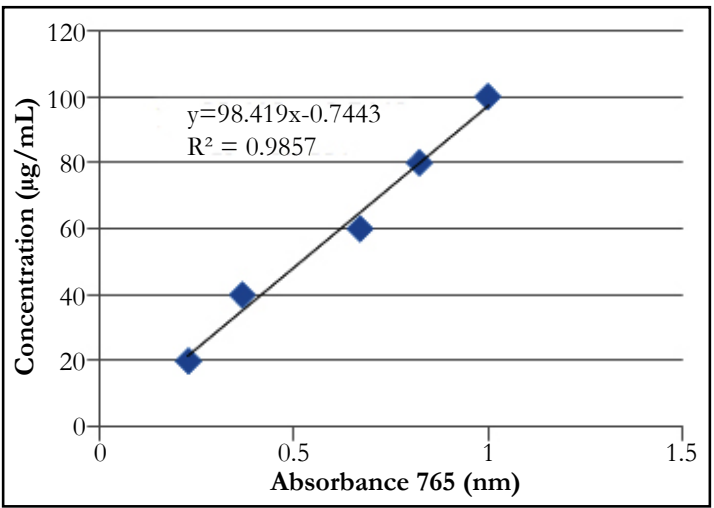

Figure 2. Standard calibration curve for the determination of total phenolic using tannic acid as a reference standard.

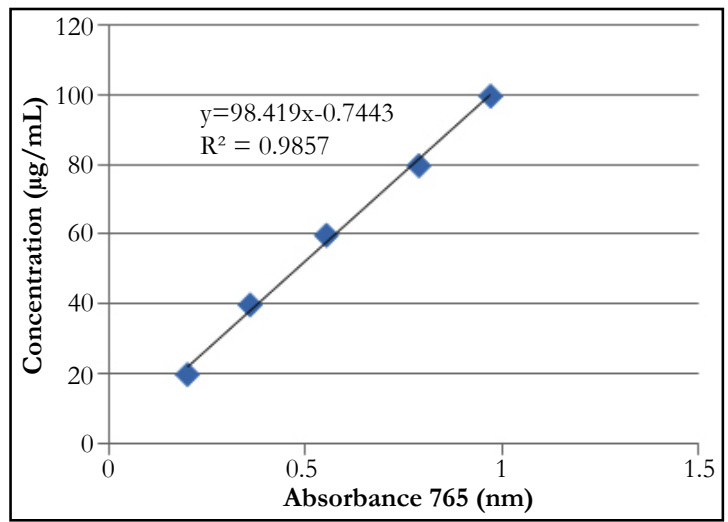


On the other hand, when tannic acid was used as a reference standard the mixture of n-hexane and ethanol (4:3) extract contained higher total phenolic content $(118.08 \mathrm{mg} / 100 \mathrm{~g} \mathrm{F.W})$ than other solvent extracts. The lower amount of total phenolic content (4.3 $\mathrm{mg} / 100 \mathrm{~g} \mathrm{F.W}$ ) was found in $\mathrm{n}$-hexane extract but a mixture of ethyl acetate and $n$ - hexane (1:1) increases the total phenolic contents $(94.53 \mathrm{mg} / 100 \mathrm{~g}$ F.W). The amount of total phenolic content in other solvent extracts like Petroleum ether, ethyl acetate, ethyl acetate: n-hexane (1:1) and ethyl acetate: ethanol (1:1) was $10.46,20.91,71.29$, and $10.12 \mathrm{mg} / 100 \mathrm{~g} \mathrm{F.W}$ respectively.

\section{Conclusions}

Results obtained from this study revealed that the highest lycopene content $(6.76 \mathrm{mg} \%)$ in tomato fruits was found in hexane: ethanol: acetone $(2: 1: 1)$ solvent extract using hexane: ethanol: acetone solvent extraction method. This method can be used for the extraction of lycopene from other sources. Highest amount of $\beta$-carotene $(3.84 \mathrm{mg} \%$ ) in tomato fruits was found in ethyl acetate extract using ethyl acetate extraction method and total phenolic contents $\left(118 . .08 \mathrm{mg}^{0}\right.$ ) was in soxhlet extract using soxhlet extraction method. This type of work will improve the quality of nutraceutical products, value added agricultural products as well as helpful to establish an industry based on the use of abundant surplus of tomato fruits and tomato processing waste in Bangladesh.

\section{Acknowledgement}

The authors are indebted to chairman of Bangladesh council of scientific and industrial research (BCSIR), director of Institute of food science and technology (IFST), BCSIR for providing all facilities to carry out this research. The authors are also grateful to Md. Nazim Uddin, scientific officer, IFST, BCSIR for his sincere help.

\section{References}

[1]. Agarwal A, Shen H, Agarwal S, Rao AV. Lycopene content of tomato products: Its stability, bioavailability and in vivo antioxidant properties. J Med Food. 2001 Spring;4(1):9-15.Pubmed PMID: 12639283

[2]. Basu A, Imrhan V. Tomatoes versus lycopene in oxidative stress and carcinogenesis: conclusions from clinical trials. Eur J Clin Nutr. 2007 Mar;61(3):295-303. Pubmed PMID:16929242.
[3]. Britton G. Czaotenoids. Meth Plant Biochem. 1991;7:473-518.

[4]. Bramley PM . Is lycopene beneficial to human health?. Phytochemistry. 2000 Jun;54(3):233-6.Pubmed PMID: 10870177.

[5]. Chanda S, Dave R. In vitro models for antioxidant activity evaluation and some medicinal plants possessing antioxidant properties: An overview. Afr J Microbiol Res. 2009 Dec 1;3(13):981-96.

[6]. Di Mascio P, Kaiser SP ,Sies H. Lycopene as the most efficient biological carotenoid singlet oxygen quencher. Arch Biochem Biophys. 1989 Nov 1;274(2):532-8. Pubmed PMID: 2802626.

[7]. Gómez-Romero M, Arráez-Román D, Segura-Carretero A, FernándezGutiérrez A. Analytical determination of antioxidants in tomato: typical components of the Mediterranean diet. J Sep Sci. 2007 Mar;30(4):452-61. Pubmed PMID: 17444214.

[8]. Giovannucci E. Tomatoes, tomato based products, lycopene and cancer: review of the epidemiological literature. J Natl Cancer Inst. 1999 Feb 17;91(4):317-31. Pubmed PMID: 10050865.

[9]. Helmenstine AM. Biochemistry of Lycopene. [Retrieved 2014 Feb 25]. Available from: http://chemistry.about.com/cs/biochemistry/a/aa050401a. htm

[10]. Kumari D, Reddy MS, Upadhyay RC. Antioxidant activity of three species of wild mushroom genus Cantharellus collected from North-Western Himalaya, India. India Int J Agric Biol. 2011 Jun 1;13(3):415-418.

[11]. Lehman JW. Operational Organic Chemistry: A Problem-Solving Approach to the Laboratory Course. 4th ed. Prentice Hall; 2009.

[12]. Lin $\mathrm{CH}$, Chen BH. Determination of carotenoids in tomato juice by liquid chromatography. J Chromatogr A. 2003 Sep 12;1012(1):103-9. Pubmed PMID: 14509347.

[13]. Livny O, Kaplan I, Reifen R, Polak- Charcon S, Madar Z, Schwartz B Lycopene inhibits proliferation and enhances gap-junction communication of KB-1 human oraltumor cells. J Nutr. 2002 Dec;132(12):3754-9. Pubmed PMID: 12468619 .

[14]. Mohsen SM, Ammar AS. Total phenolic contents and antioxidant activity of corn tassel extracts. Food chemistry. 2009 Feb 1;112(3):595-8.

[15]. Organic Herb Inc. Tomato Extract Lycopene. 2012. [Retrieved 2013 June 26]. Available from:http://www.organic-herb.com/Product/Item/75.html

[16]. Rao AV, Agrawal S. Role of antioxidant lycopene in cancer and heart disease. J Am Coll Nutr. 2000 Oct;19(5):563-9. Pubmed PMID: 11022869.

[17]. Rissanen T, Voutilainen S, Nyyssönen K, Salonen JT. Lycopene, atherosclerosis and coronary heart disease. Exp Biol Med (Maywood). 2002 Nov;227(10):900-7. Pubmed PMID: 12424332.

[18]. Taungbodhitham AK, Jones GP, Wahlqvist ML, Briggs DR. Evaluation of extraction method for the analysis of carotenoids in fruits and vegetables. Food chemistry. 1998 Dec 1;63(4):577-84.

[19]. Upritchard JE, Sutherland WH, Mann JI. Effect of supplementation with tomato juice, vitamin $\mathrm{E}$ and vitamin $\mathrm{C}$ on LDL oxidation and products of inflammatory activity in type 2 diabetes. Diabetes Care. 2000 Jun;23(6):7338. Pubmed PMID: 10840987.

[20]. Pasupuleti V, Kulkarni SG. Lycopene fortification on the quality characteristics of beverage formulations developed from pink flesh guava (Psidiumguajava L.). J Food Sci Technol. 2014 Dec;51(12):4126-31. Pubmed PMID: 25477692.

[21]. Wolfe K, Wu X, Liu RH. Antioxidant activity of apple peels. J Agric Food Chem. 2003 Jan 29;51(3):609-14.

[22]. Zhou K, Yu L. Effects of extraction solvent on wheat bran antioxidant activity estimation. LWT-Food science and Technology. 2004 Nov 1;37(7):71721. 